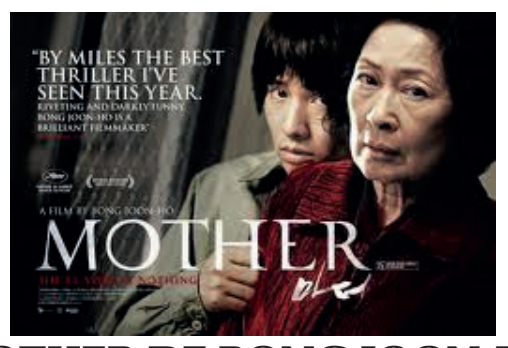

MOTHER DE BONG JOON-HO

Puede existir y de hecho existe cierto extrañamiento en esa especie de prólogo de Mother, ese plano de la protagonista mirando a cámara y bailando en un campo desierto, no tanto si esperamos a completar el visionado del film.

El realizador coreano tiene respeto por sus criaturas, su vida, su intimidad, de manera un tanto pudorosa, purista, al tiempo dotada de una falsa necesidad serena que va creando tramas posibles, cuyo objetivo es dar a conocer la verdad, partiendo de cierto localismo donde convive cierto humor negro, con un análisis críptico social sin desprenderse de una trama negra, que en este caso conversa con el melodrama donde predomina un tono lúgubre, gris cenital, que intensifica el dramatismo, así mismo emotivo, triste, preciso -en este caso centrado en la figura de la madre, mater amantísima que pasa de ser figura central del drama familiar para convertirse gradualmente en una especie de investigadora policial que trata de defender a un hijo al que se le acusa de asesinato, cuando la cinta se adentra en la trama criminal, excepcional por cierto interpretación de la actriz Kim Hye-ja-; otra muestra más de hibridación de géneros suficientemente interrelacionados, siempre en confrontación con el mundo real - estilo propio, cuidadosa composición del plano, preciso empleo de movimientos de cámara, sorpresivas elipsis, rimas en el montaje-.

Por lo tanto los personajes luchan contra sí mismos, sus creencias, también vivencias, emociones, una vez que los acontecimientos les son contrarios, una pugna interna cuyas decisiones tomadas marcan el territorio, un hecho diferenciador que les aleja del entorno, una vez que han perdido confianza en este, y les sumerge en todo un proceso vampírico al tiempo marginal, sufriendo con intensidad, basculando entre la lucidez y la locura, intentando poner orden a tanto desorden, aunque tengan que traicionar su ética, sin dejar de tener un amor cercano a los suyos, incluso por encima de la justicia.

\title{
Ficha técnica:
}

Director: Bong Joon-ho

Guión: Eun-kyo Park, Bong Joon-ho, Wun kyo Park

Montaje: Sae- kyoung Moon

Reparto: Kim Hye-ja, Won Bin, Jin Ku, Yun Je-mun, Jun Mi-sun, Song Sae-Byeok, Chun Woo-hee

Fotografía: Alex Hong Música: Lee Byung-woo Corea del Sur, 2009 